\title{
Culture of brachyuran crab larvae using a re-circulating sea water system in the laboratory*
}

\author{
A. N. SASTRY \\ Graduate School of Oceanograpby, University of Rhode-Island; \\ Kingston, Rhode Island, USA
}

KURZFASSUNG: Die Züchtung von Brachyuren-Larven im Labor mittels eines rezirkulierenden Seewassersystems. Bei der Züchtung von Brachyurenlarven bis zum Jungtier hat sich die Möglichkeit ergeben, einige Probleme der OKkologie und Physiologie mariner Organismen zu untersuchen. Die bisher allgemein gebräuchliche Methodik (CostLow \& BRooKнout 1960) erfordert eine sorgfältige Pflege der Entwicklungsstadien und ist für die Gewinnung großer Mengen, wie sie für die experimentelle Arbeit benötigt werden, zu zeitraubend. Eine Methode, die eine Massenkultur ermöglicht, ist daher für experimentelle Untersuchungen von besonderer Bedeutung. Sie ist außerdem Voraussetzung für die Zucht von Meeresorganismen auf wirtschaftlicher Basis. Um geeignete Methoden für die Massenkultur zu entwickeln, die eine möglichst hohe Überlebensrate gewährleisten, ist es notwendig, die Lebensansprüche der Larven während sämtlicher Phasen des Lebenszyklus zu kennen. Die Larven von Cancer irroratus und Panopeus herbstii wurden über alle Entwicklungsstadien bis zum ersten Juvenilkrebsstadium gezüchtet. Die optimalen Temperatur- und Salzgehaltsansprüche für die vollständige Entwicklung wurden durch die Züchtung unter verschiedenen Faktorenkombinationen ermittelt. Für die Laboratoriums-Massenkultur der Larven beider Arten wurde ein SeewasserRezirkulationssystem entworfen und hergestellt. In diesem System wurden die Larven beider Arten unter kontrollierten Bedingungen erfolgreich bis zum ersten Krebsstadium gezüchtet. Die Überlebensrate war bei den Larven von $P$, herbstii größer als bei denen von $C$. irroratus.

\section{INTRODUCTION}

Rearing brachyuran crab larvae through all stages of their development to juveniles in the laboratory has provided opportunities in recent years to study a number of problems in physiology and ecology of marine organisms. The understanding of environmental requirements for the development of larval stages is helpful for culturing the larvae under conditions yielding best survival. Raising larvae to juveniles provides opportunities for detailed studies in physiology, biochemistry, genetics, and behavior. Another aspect of mass raising larvae to juveniles is large scale production of economically important marine organisms or aquaculture (RYTHER \& BARDACH 1968).

* These studies were aided by grants from the National Science Foundation, Sea Grant College Program at the University of Rhode Island, Kingston, Rhode Island, USA. 
Costlow \& Bookнout (1960) developed a method of raising brachyuran crab larvae to juveniles in the laboratory. In general, the method is to hatch eggs in the laboratory, to procure larvae and to care for them by providing suitable food and frequent changes of sea water. This method requires much time and, therefore, it is not well suited for extensive experimental studies or aquaculture. However, it is particularly valuable for recognizing different larval stages and for gaining initial insight into basic environmental requirements for best survival of each larval stage (CostLow \& Bookhout 1962).

The objectives of the present study are: (1) to determine the temperature and salinity requirements for larval development and best survival of Cancer irroratus (SAY) and Panopeus herbstii Minne-Edwards; (2) to examine the possibility of culturing the larvae under optimum physical environmental conditions in a re-circulating sea water system in the laboratory.

\section{MATERIAL AND METHODS}

Ovigerous females of Cancer irroratus were collected from Narragansett Bay, Rhode Island (USA), by trawling at a depth of 8 to $10 \mathrm{~m}$. Egg masses were removed from crabs brought to the laboratory and placed in large finger bowls containing filtered sea water treated with penicillin. The strands of eggs were isolated from the pleopods and then washed several times with fresh filtered sea water. A small number of eggs were placed in compartments of plastic boxes containing 30 to $40 \mathrm{ml}$ of $30 \%$ salinity sea water containing penicillin. The boxes were maintained at $10^{\circ}, 15^{\circ}$ and $20^{\circ} \mathrm{C}$ with a photoperiod of $14 \mathrm{~h}$ light and $10 \mathrm{~h}$ darkness. Only larvae hatched from the eggs maintained at $15^{\circ} \mathrm{C}$ were used in the present study. The larvae were raised employing the method described by Costrow \& Bookнout (1960). When larvae were raised from eggs, a single larva was placed in each compartment of the plastic boxes containing approximately 30 to $40 \mathrm{ml}$ filtered sea water. The larvae were exposed to the following combinations of temperature and salinity: $10^{\circ}, 15^{\circ}, 20^{\circ} \mathrm{C}$; $20 \%, 25 \%, 30 \%, 35 \%$. They were daily fed freshly hatched nauplii of Artemia salina; the sea water was changed frequently. The larvae were examined each day to record survival and molting.

Ovigerous females of Panopeus herbstii were collected in July, 1969, from an oyster bed in the Pawcatuck River (USA) which forms a boundary between Rhode Island and Connecticut. The eggs were incubated at $20^{\circ} \mathrm{C}$ and, after hatching, the larvae were transferred into $32 \%$ salinity at $20^{\circ}$ and $25^{\circ} \mathrm{C}$ respectively. The larvae were examined each day for recording survival and molting.

\section{LARVAL DEVELOPMENT OF CANCER IRRORATUS}

First stage zoeae were released from the eggs hatched in the laboratory. There are 5 zoeal stages and 1 megalops stage in the development of Cancer irroratus. The megalops molted into the first crab stage. The detailed description of morphological 
characteristics of each stage in the development of $C$. irroratus will be given elsewhere (SASTRY unpublished).

\section{Temperature-salinity effects on larval development}

The percent mortality in each stage of development of Cancer irroratus larvae reared in different temperature-salinity combinations is shown in Figure 1. The mortality of first stage zoea was highest in $15 \%$ and $20 \% \mathrm{~S}$ at the three different

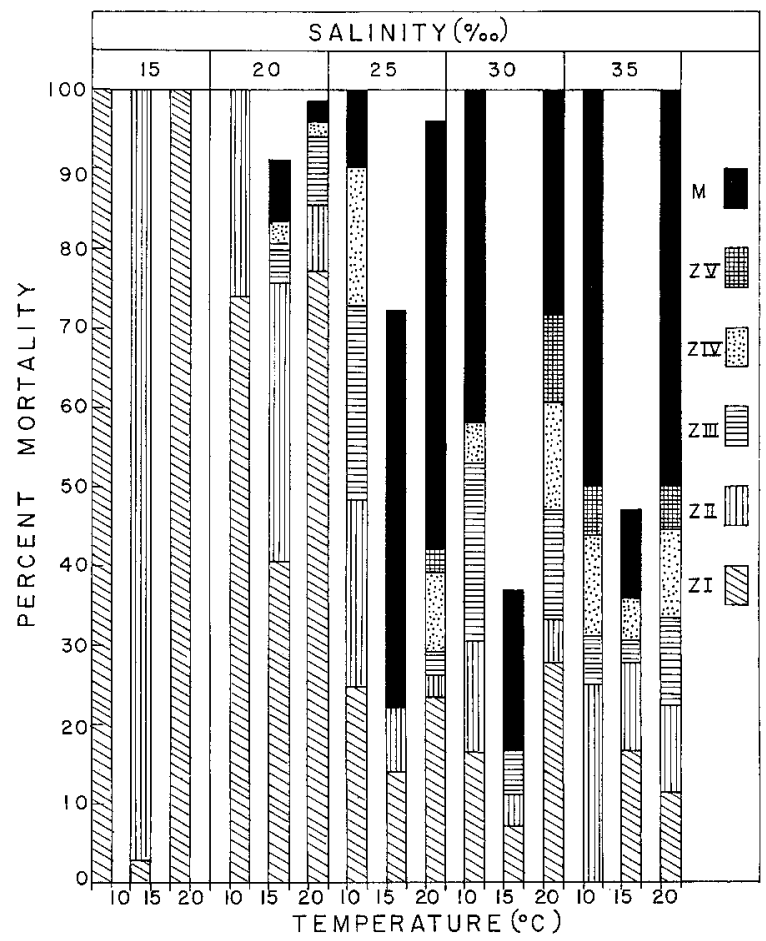

Fig. 1: Percent mortality of each stage of Cancer irroratus larvae reared in different temperature-salinity combinations. Z I-Z V zoeal stages, $M$ megalop stage

constant temperatures employed. The first zoeal stage was not completed in $15 \% \mathrm{~S}$ at $10^{\circ}$ and $20^{\circ} \mathrm{C}$. The mortality of the second zoeal stage was highest in salinities between $25 \%$ and $35 \%$ at $10^{\circ} \mathrm{C}$. In $15 \% 00 \mathrm{~S}$ at $15^{\circ} \mathrm{C}$, the second zoeal stage was not completed. The mortality of the third and fourth zoeal stages was highest at $10^{\circ}$ and $20^{\circ} \mathrm{C}$. The highest mortality of the fifth zoeal stage was observed in the higher salinities at $20^{\circ} \mathrm{C}$. The megalops stage was reached in all salinities between $20 \%$ and $35 \%$ at the three temperatures. The only exception was in $20 \%$ S at $10^{\circ} \mathrm{C}$. Mortality of the megalops stage was highest in the following temperature- 
salinity combinations: $30 \%$ and $35 \% \mathrm{~S}$ at $100 \mathrm{C} ; 25 \% \mathrm{~S}$ at $15^{\circ} \mathrm{C} ; 25 \%$ and $35 \% \mathrm{~S}$ at $20^{\circ} \mathrm{C}$.

The percentages of the initial number of larvae which developed to megalops and crab stage in different temperature-salinity combinations are shown in Figure 2. The survival of larvae to the megalops stage was highest in $25 \%, 30 \%$ and $35 \% \mathrm{~S}$ at $15^{\circ} \mathrm{C}$.

The megalops metamorphosed to the first crab stage in most salinities at $15^{\circ} \mathrm{C}$, in $25 \% \mathrm{~S}$ at $20 \% \mathrm{C}$. The survival to the furst crab stage was highest in $30 \% 00$ and $35 \% \mathrm{~S}$ at $15^{\circ} \mathrm{C}$. The metamorphosis of megalops to the first crab stage seems to be affected more by the differences in temperature than those in salinity.

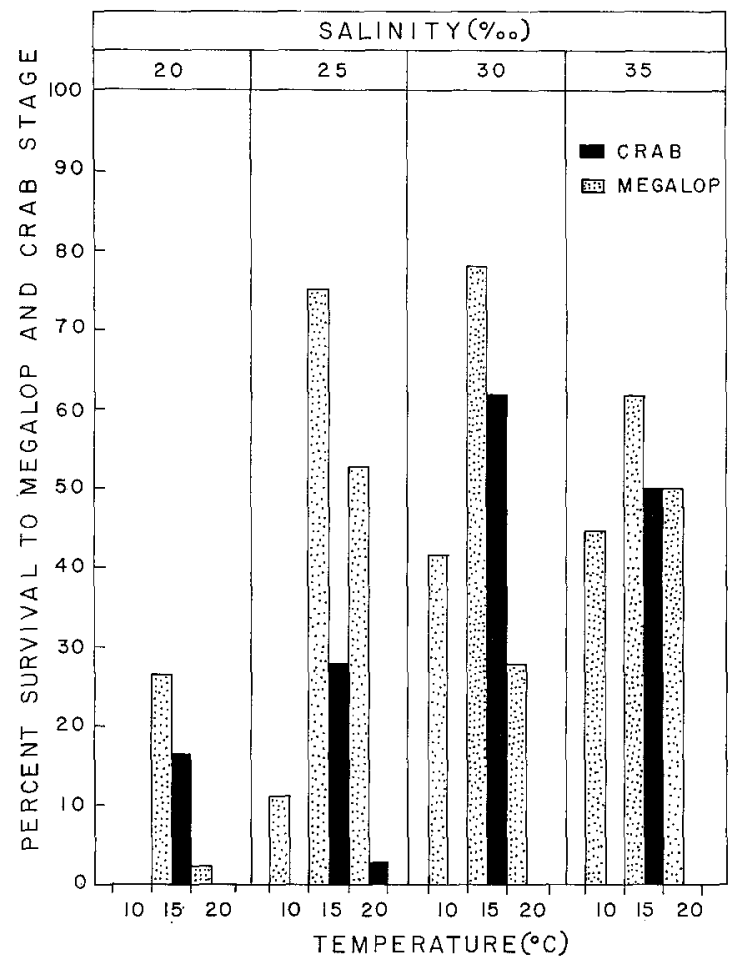

Fig. 2: Percent of initial number of Cancer irroratus larvae which completed development to megalops and crab stage in different temperature-salinity combinations

After the larvae completed the final zoeal molt to the megalops in $30 \% \mathrm{~S}$ at $15^{\circ} \mathrm{C}$, they were transferred into different temperature-salinity combinations. The percentages of megalops which metamorphosed to the first crab in different temperature-salinity combinations are given in Table 1 . At $10^{\circ} \mathrm{C}$, the first crab stage was attained only in $35 \% \mathrm{~S}$. In $15 \%$ salinity at $20 \% \mathrm{C}$, the megalops did not metamorphose to the first crab stage. Metamorphosis of megalops to the first crab stage was observed in all other temperature-salinity combinations. Survival to the first crab stage was highest in $30 \% \mathrm{~S}$ at $15^{\circ} \mathrm{C}$. 
Table 1

Cancer irroratus. Percentages of megalops stages which metamorphosed to the first crab stage in different salinity-temperature combinations. The zoeal stages had been kept in $30 \% \mathrm{~S}$ at $15^{\circ} \mathrm{C}$

\begin{tabular}{|c|c|c|c|c|c|c|c|}
\hline \multirow{2}{*}{ Salinity } & \multirow{2}{*}{$\begin{array}{l}\text { Number } \\
\text { of larvae }\end{array}$} & \multicolumn{2}{|c|}{$10^{\circ} \mathrm{C}$} & \multicolumn{2}{|c|}{$\begin{array}{c}\text { Temperature } \\
15^{\circ} \mathrm{C}\end{array}$} & \multicolumn{2}{|c|}{$20^{\circ} \mathrm{C}$} \\
\hline & & $\begin{array}{l}\text { Percent } \\
\text { crabs }\end{array}$ & Days & $\begin{array}{l}\text { Percent } \\
\text { crabs }\end{array}$ & Days & $\begin{array}{l}\text { Percent } \\
\text { crabs }\end{array}$ & Days \\
\hline $15 \%$ & 18 & 0 & - & 5.5 & 31 & 0 & - \\
\hline $20 \%$ & 18 & 0 & - & 16.6 & 23 & 5.5 & 15 \\
\hline $25 \%$ & 18 & 0 & - & 26.6 & 23 & 5.5 & 17 \\
\hline $30 \%$ & 18 & 0 & - & 76.3 & $14-30$ & 26.6 & $11-14$ \\
\hline $35 \%$ & 18 & 5.5 & 29 & 44.4 & $16-19$ & 5.5 & 17 \\
\hline
\end{tabular}

\section{Rate of development}

The minimum and maximum periods of time required for development of zoeae, megalops and crab stages in $30 \%$ salinity at $150 \mathrm{C}$ is shown in Figure 3 . The duration of zoea development was not affected appreciably by the differences in salinity. The larvae reared in $30 \% \mathrm{~S}$ required less time for completion of zoeal

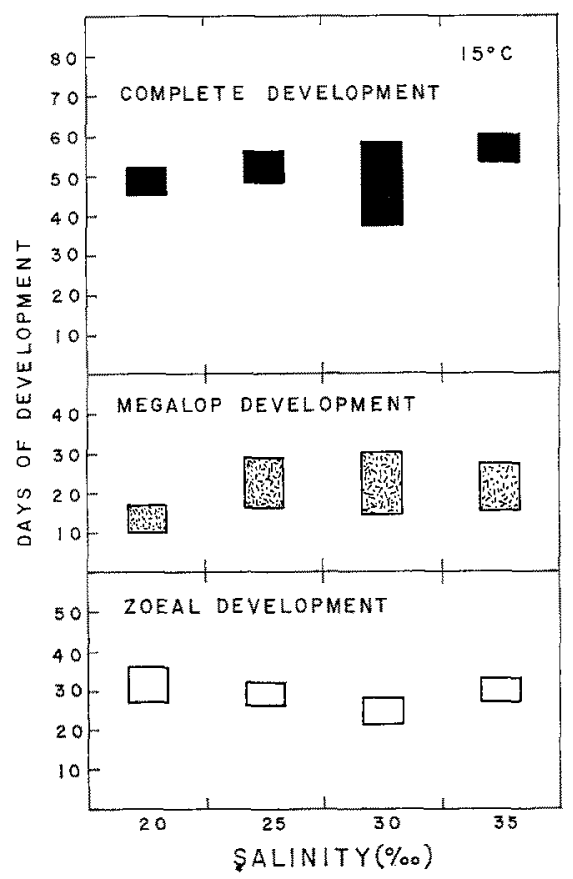

Fig. 3: Minimum and maximum time for zoeal development, megalops development and total development to the crab stage for larvae of Cancer irroratus reared in different salinities at $15^{\circ} \mathrm{C}$ 
development. The duration of megalops development was also not affected by the differences in salinity. Megalops development was slightly delayed in higher salinities. The time required for completing the development to the first crab stage was approximately the same in all four salinities. In $30 \% \mathrm{~S}$, the minimum and maximum number of days required for complete development to the first crab stage was greater than in the other salinities.

The periods of time required for metamorphosis of megalops to the first crab stage in different temperature-salinity combinations are listed in Table 1 . The duration of megalops metamorphosis to the first crab stage seems to be affected by the differences in temperature. Salinity differences do not seem to exert a pronounced influence on the time required for metamorphosis to the crab stage.

\section{LARVAL DEVELOPMENT OF PANOPEUS HERBSTII}

The larvae of Panopeus herbstii have been reared through all developmental stages to the first crab stage. Costlow \& Bookнout (1961) observed 4 zoeal stages and 1 megalops stage in the larval development of this species (North Carolina) and described the morphological characteristics of each stage. In the larval development of $P$. berbstii collected from Rhode Island 4 zoeal stages and 1 megalops stage also occur.

Costlow et al. (1962) determined the effect of temperature and salinity on larval development of Panopeus berbstii. They found no optimum combination for

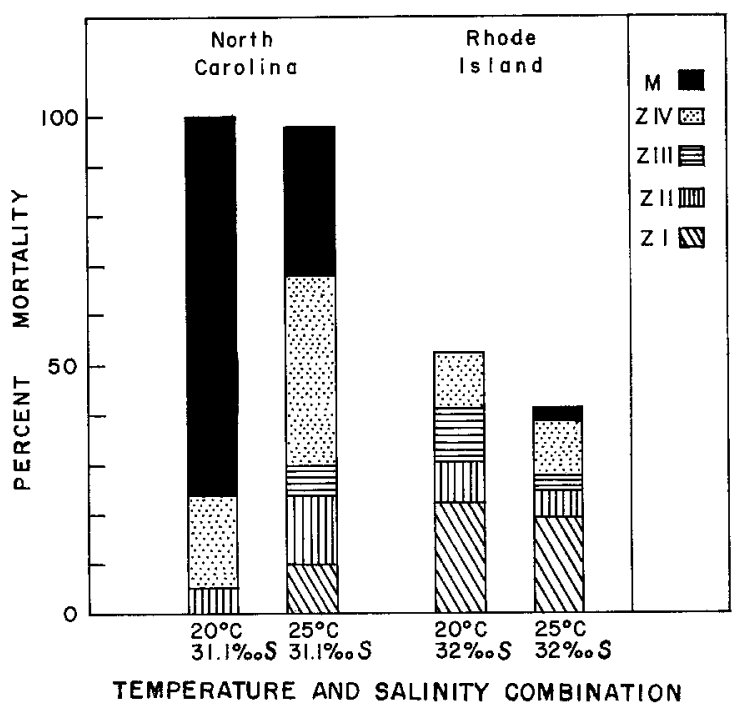

Fig. 4: Percent mortality of different stages in the larval development of Panopeus berbstii populations. The data for the North Carolina populations are taken from Costlow \& BookHout (1962). Z I-Z IV zoeal stages, M megalop stage 
each stage; any one larval stage is sensitive to a particular salinity. The highest survival rates were observed at the higher temperatures $25^{\circ}$ and $30^{\circ} \mathrm{C}$.

Mortality of first and fourth zoeal stages was highest in the larval development of the population of Panopeus berbstii from Rhode Island (Fig. 4). The time required for larval development of the Rhode Island population was less than in the North Carolina population, even though both populations were raised under approximately identical environmental conditions (Fig. 5).

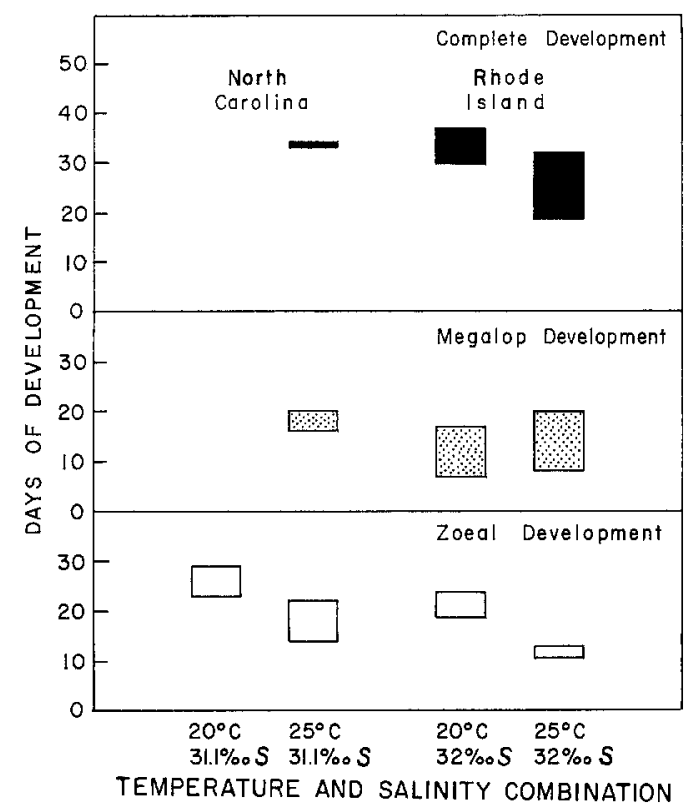

Fig. 5: Minimum and maximum time for zoeal development, megalops development and development to the first crab stage for larvae of Panopeus berbstii. The data for the North Carolina population are taken from CostLow \& BookHout (1962)

\section{CULTURE OF LARVAE IN THE RE-CIRCULATING SEA WATER SYSTEM}

To attempt mass culture of larvae, a sea water system with controlled environmental conditions suitable for development and best survival is needed. The system should require minimum time for maintenance during its operation and care for the larvae during their development. A re-circulating sea water system with controlled environmental conditions has been designed and fabricated for culture of crab larvae in the laboratory (Fig. 6). The construction of the sea water system included: (1) controls for maintaining constant physical environmental conditions; (2) a method of removing the waste material; and (3) a method of purification of sea water to slow its rate of deterioration. 


\section{Flow of sea water}

The description of the sea water system is given following the flow of sea water from the reservoir. The sea water from the reservoir flows into the culture tank by siphoning action and slight positive pressure developed by aeration of water in the partially closed container. The water from the culture tank is lifted by a variable speed peristaltic Masterflex tubing pump (Cole-Palmer, New York) and returned to

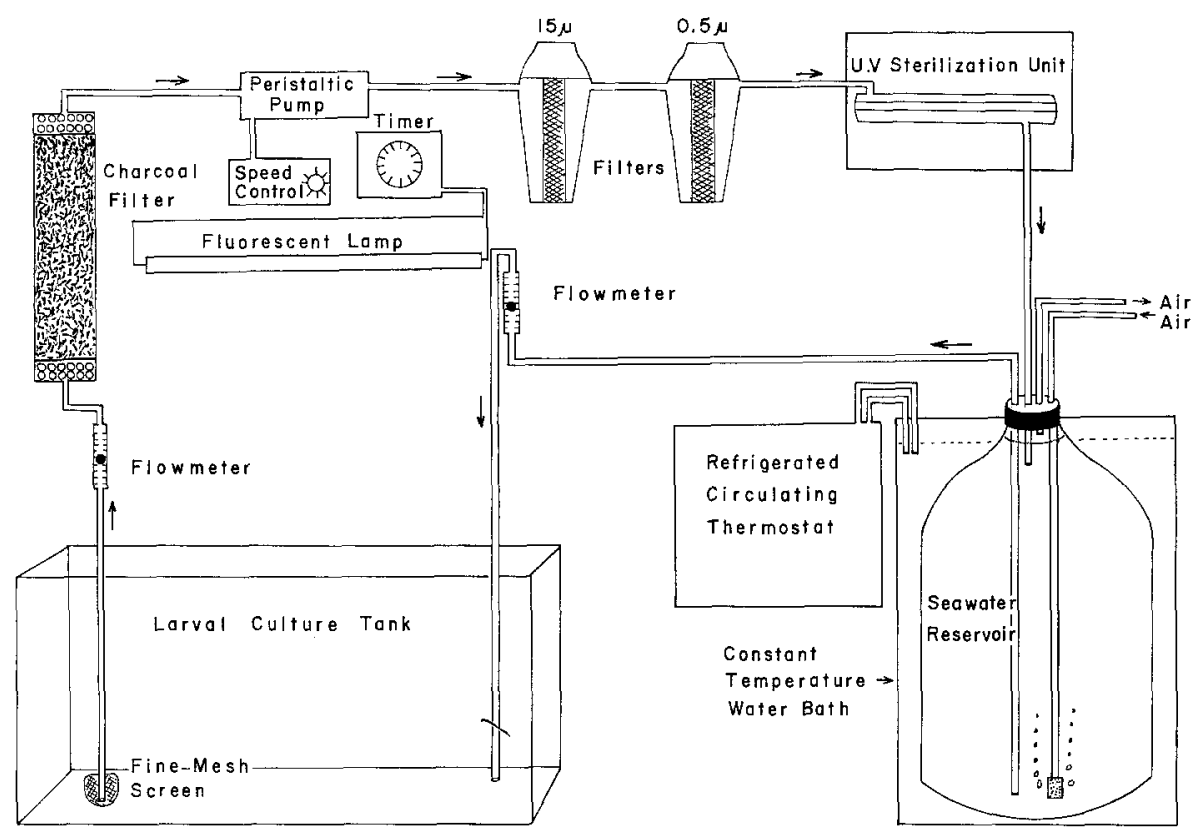

Fig. 6: Schematic diagram of the re-circulating sea water system employed

the reservoir. To retain the larvae in the culture tank, the intake of the outflow has been covered with a fine mesh nitex cloth screen. The reservoir and the culture tank were filled initially with 601 and 101 respectively of millipore filtered sea water (Type HA $0.45 \mu$, Millipore Corp., Bedford, Mass., U.S.A.). Also, $120 \mathrm{ml}$ of Streptomycin stock solution $(2 \mathrm{~g} / 1)$ and $120 \mathrm{ml}$ of Sulmet stock solution (Sulfamerazine $0.3 \mathrm{~g} / 1)$ were added to the sea water. A flow rate of $80 \mathrm{ml} / \mathrm{min}$ has been maintained during the operation of the sea water system. A constant water level in the culture tank was maintained by adjusting the rate of inflow and outflow of the sea water.

\section{Environmental control}

A constant sea water temperature optimum for development and best survival of larvae has been maintained in the culture tank. The temperature of sea water has been controlled by placing the sea water reservoir in a large constant temperature 
water bath. The bath temperature has been regulated by a refrigerated circulating thermostat (Nes Lab, Durham, N.H., U.S.A.). The temperature of the water bath has been adjusted to maintain the desired sea water temperature in the culture tank. Once the desired sea water temperature in the culture tank has been adjusted, it remains fairly constant throughout the period of operation of the system. Photoperiod has been regulated to provide $14 \mathrm{~h}$ light and $10 \mathrm{~h}$ darkness by a timer controlled fluorescent lamp.

The reservoir and the culture tank were initially filled with sea water of the desired salinity and which remained at approximately the same concentration during the operation of the system.

\section{Filtration and purification}

The sea water from the culture tank was passed through a column filled with cocoanut charcoal to trap the waste material and absorb the dissolved gases. The sea water was then passed through Orlon-would cartridge filters (Commercial Filters Corp., Lebanon, Ind., U.S.A.) of $15 \mu$ and $0.5 \mu$ pore diameter arranged in diminishing pore size. The filtered sea water was then passed over a U.V. lamp for sterilization. The filtered and sterilized sea water was then returned to the reservoir tank.

\section{Development and survival of larvae}

The first stage zoea of Cancer irroratus were added to the sea water in the culture tank. The larvae swam up to the surface and concentrated along the corners of the rectangular tank. Freshly hatched Artemia salina nauplii were added each day as food. The mortality of larvae was negligible during the first week they were maintained in the culture tank. In the beginning of the second week, the larvae began to stay more on the bottom and this behaviour was apparently associated with molting. A large number of exuviae and a slight algal growth was observed on the bottom of the tank during the second week. During the third week, the total number of larvae

Table 2

Survival of larvae of Cancer irroratts and Panopeus berbstii to megalop and crab stage in the re-circulating sea water system

\begin{tabular}{|c|c|c|c|c|c|c|c|}
\hline \multirow{2}{*}{$\begin{array}{l}\text { Culture } \\
\text { method }\end{array}$} & \multirow{2}{*}{$\begin{array}{l}\text { Temper- } \\
\text { ature } \\
\left({ }^{0} \mathrm{C}\right)\end{array}$} & \multirow{2}{*}{$\begin{array}{c}\text { Sa- } \\
\text { linity } \\
(\% 0)\end{array}$} & \multirow{2}{*}{$\begin{array}{c}\text { Initial } \\
\text { number } \\
\text { of Iarvae }\end{array}$} & \multicolumn{2}{|c|}{ To megalop } & \multicolumn{2}{|c|}{ To crab } \\
\hline & & & & Survival & Days & Survival & Days \\
\hline \multicolumn{8}{|c|}{ Cancer irroratus } \\
\hline System & 15 & 30 & 4,800 & $64 \quad(1.3 \%)$ & $28-43$ & $3(0.06 \%)$ & $43-58$ \\
\hline Plastic boxes & 15 & 30 & & $43(79.6 \%)$ & $21-28$ & $33(61.1 \%)$ & $37-58$ \\
\hline \multicolumn{8}{|c|}{ Panopeus berbstii } \\
\hline System & 25 & 32 & 4,000 & $1,546(38.6 \%)$ & $11-15$ & $139(3.47 \%)$ & $28-37$ \\
\hline Plastic boxes & 25 & 32 & 36 & $20(55.5 \%)$ & $11-13$ & $19(52.7 \%)$ & $19-34$ \\
\hline
\end{tabular}


was reduced to 500 . The larvae developed to the megalops stage between day 28 and 43 . The megalops were less active than the earlier zoeal stages and they remained more on the bottom of the culture tank. The mortality during the megalop development was also high. However, the megalops metamorphosed to the first crab stage in the system. The crabs went through further molts before the operation of the system was terminated on day 58. During the entire period of operation, the temperature of sea water remained about $15^{\circ} \mathrm{C}$, the salinity $30 \%$. On three occasions, however, the temperature of sea water in the system increased to about $25^{\circ} \mathrm{C}$, when difficulties were experienced with the refrigerated circulating thermostat. The survival of larvae and duration for development to the megalop and the first crab stage is given in Table 2.

First stage zoea of Panopens herbstii, immediately after hatching from the eggs, were introduced into the sea water in the culture tank. Temperature and salinity were maintained at $25^{\circ} \mathrm{C}$ and $32 \% \mathrm{~S}$ respectively. The larvae were offered freshly hatched Artemia salina nauplii each day as food. All zoeal stages of $P$. herbstii were more phototactic than those of Cancer irroratus and remained most of the time in the surface water of the culture tank. There was very little mortality during the development of zoeal stages. Mortality was highest during the final zoeal molt and the megalops development of $P$. herbstii. The megalops remained on the bottom of the culture tank and showed little swimming activity. They completed development to the first crab stage in the sea water system. Survival data of larvae and duration of development to megalops and first crab stage are presented in Table 2.

\section{CONCLUSIONS}

The basic pre-requisite for successful cultivation of larvae of marine organisms is, obviously, an understanding of their environmental requirements for completion of the different life cycle stages. The evaluation of optimum environmental requirements for each stage in the development would allow to culture larvae under conditions suitable for best survival. Rearing of individually maintained larvae is valuable for identification of each larval stage and for the study of its environmental requirements. Such information is necessary for developing methods allowing mass cultivation of larvae for large scale production of juveniles under controlled environmental conditions.

The larvae of Cancer irroratus cultured under optimum physical environmental conditions in the re-circulating sea water system completed their development to the first crab, but the survival rates were relatively poor. In comparison, the larvae of Panopeus berbstii survived better through all zoeal stages and the megalops stage. It appears possible to improve larval survival rates in the sea water system used on the basis of a better understanding of the major factors involved. Survival rates of larvae in the sea water system may have been affected by (1) hardiness of larvae, (2) crowding, (3) accumulated waste material on the bottom of the culture tank, (4) changing quality of sea water, and (5) competition for food. With further refinement of the sea water system employed it might be possible to mass culture the larvae to juveniles. 


\section{SUMMARY}

1. Larvae of Cancer irroratus were raised in the laboratory from the first zoeal stage to the first crab stage. Five zoeal stages and one megalops stage were observed during development to the first crab stage.

2. The larvae developed to the megalops stage in salinities of $20 \%, 25 \%, 30 \%$ and $35 \%$, and at temperatures of $10^{\circ}, 15^{\circ}$ and $20^{\circ} \mathrm{C}$. The megalops metamorphosed in all the four salinities at $15^{\circ} \mathrm{C}$, and in $25 \%$ at $200 \mathrm{C}$. A temperature-salinity combination of $15^{\circ} \mathrm{C}$ and $30 \% \mathrm{~S}$ was found to allow maximum survival of larvae until the crab stage. The different salinities do not seem to affect greatly the duration for zoeal development, megalops development and total development to the crab stage at $15^{\circ} \mathrm{C}$.

3. The larvae of Panopeus herbstii were also raised to the first crab stage in the laboratory at $20^{\circ}$ and $25^{\circ} \mathrm{C}$ and $32 \% \mathrm{~S}$. There were four zoeal stages and one megalop stage during complete development in the laboratory.

4. A re-circulating sea water system has been designed and fabricated for cultivation of crab larvae under controlled environmental conditions in the laboratory. The larvae of $C$. irroratus and $P$. berbstii, cultured in the sea water system, completed their development to the first crab stage.

Acknowledgement. The author wishes to thank Mr. J. ZISKowsKI for excellent technical assistance throughout this study.

\section{LITERATURE CITED}

Costlow, J. D. \& Bookнout, C. G., 1960. A method of developing brachyuran crab eggs in vitro. Limnol. Oceanogr. 5, 212-215.

- - 1961. The larval stages of Panopeus herbstii MiLne-EDwards reared in the laboratory. J. Elisha Mitchell scient. Soc. 77, 33-42.

- - 1962. The effect of environmental factors on larval development of crabs. In: Biological problems in water pollution, 3rd. Seminar. Pl. and ass. by C. M. Tarzwell. U.S. Dep. of Health, Education and welfare, Cincinnati, Ohio, 77-86 (Publ. Hlth Serv Publs, Wash. 999 - WP - 25).

Costrow, J. D., Boокhout, C. G. \& Monroe, R., 1962. Salinity-temperature effects on the larval development of the crab Panopeus berbstii MILNE-EDWARDs reared in the laboratory. Physiol. Zoöl. 35, 79-93.

Ryther, J. H. \& Bardach, J. E., 1968. The status and potential of aquaculture. Vol. 1. Particularly invertebrates and algae culture. Clearing House for Federal Scientific and Technical Information, Springfield, Va, $260 \mathrm{pp}$.

SASTRY, A. N. Larval development of Cancer irroratus (SAY) reared in the laboratory. (Unpubl.)

Author's address: Dr. A. N. SASTRY

Graduate School of Oceanography

University of Rhode Island

Kingston, R.I. 02881, U.S.A. 